\title{
Paradoxical effect of smoking following acute myocardial infarction
}

\author{
Giuliana Durighel $^{1 *}$, Tim Dawes ${ }^{1}$, Clare Ashwin' ${ }^{1}$, Stuart A Cook ${ }^{1,2}$, Declan P O'Regan ${ }^{1,2}$ \\ From 16th Annual SCMR Scientific Sessions \\ San Francisco, CA, USA. 31 January - 3 February 2013
}

\section{Background}

Cigarette smoking causes coronary endothelial dysfunction and is a major risk factor for ischemic heart disease and acute ST-elevation myocardial infarction (STEMI) [1]. Prior studies have found that the mortality rate of smokers after AMI may paradoxically be lower than in non-smokers [2]. Epidemiological studies have failed to find a dosedependent relationship between cardiovascular risk and the number of cigarettes smoked [3]. We used CMR to analyse myocardial infarct size and salvage \% in patients following primary percutaneous coronary intervention (PPCI), categorising smokers as never-, ex- and current smokers.

\section{Methods}

In a prospective single-centre study sixty one patients underwent CMR on a 1.5T Philips Achieva (Best, Netherlands) during the first week following PPCI for acute STEMI. The ischemic area-at-risk was assessed with T2weighted imaging and myocardial necrosis with late gadolinium enhancement. Myocardial salvage quantification was performed using certified analysis software $(\mathrm{cmr} 42$, Circle Cardiovascular Imaging, Alberta, Canada) (Fig 1). Statistical analysis was carried out using SPSS 19.0 (IBM, Armonk, NY).

\section{Results}

Infarct size was normally distributed (by Normal plots and Shapiro Wilk testing). Univariate regression analysis showed smoking status was the only factor significantly associated with infarct size ( $\mathrm{R} 2=0.085, \mathrm{p}=0.02)$ (Fig 2). Univariate regression analysis also showed pain-to-balloon time to be the only factor significantly associated with salvage $(\mathrm{R} 2=0.085, \mathrm{p}=0.02)$.

${ }^{1}$ Robert Steiner MR Unit, Imperial College, London, UK

Full list of author information is available at the end of the article
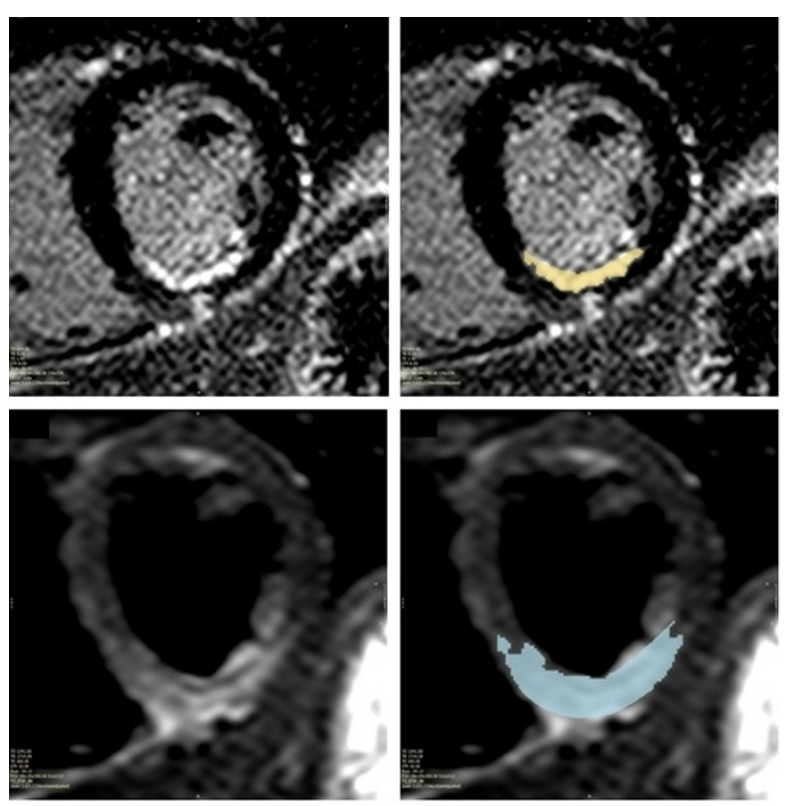

Figure 1 Quantification of myocardial necrosis (upper) and salvage (lower) on MRI following PPCl in a current smoker.

\section{Conclusions}

Smoking is associated with smaller infarcts but is not an independent predictor of myocardial salvage. This study further highlights the debate surrounding the "smokers' paradox". Ischemic pre-conditioning, as well as favourable baseline clinical and angiographic characteristics, may be responsible for the more benign prognosis of current smokers [4]. Adaptations in the coronary microcirculation and the subsequent response to ischemiareperfusion injury may underlie the pathophysiological differences seen in smokers [5].

\section{Funding}

No external funding sources. 


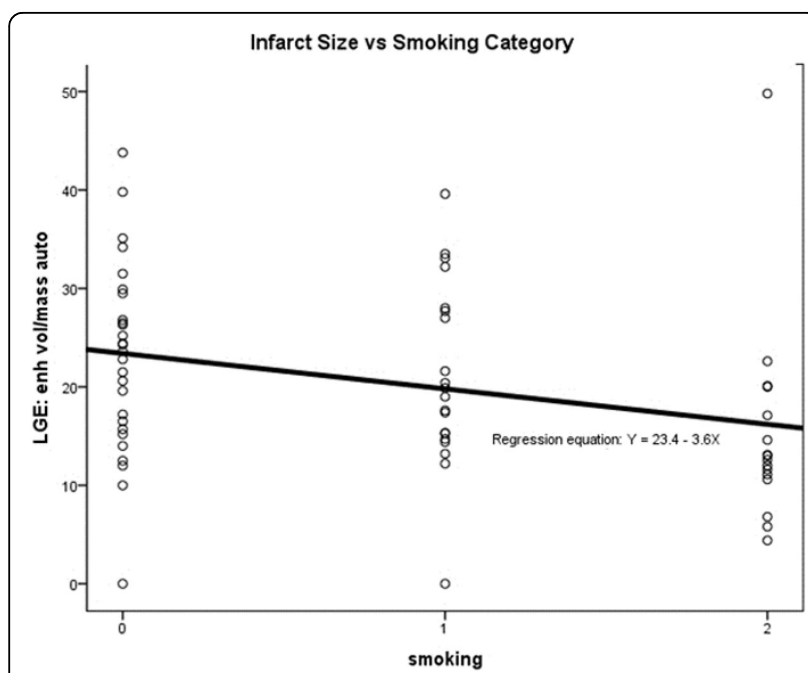

Figure 2 Association of smoking on infarct size. $0=$ Never Smoked 1= Ex-smoker 2= Current Smoker.

\section{Author details}

${ }^{1}$ Robert Steiner MR Unit, Imperial College, London, UK. ${ }^{2}$ Institute of Clinical Science, Imperial College, London, UK.

Published: 30 January 2013

\section{References}

1. Rahman MM, et al:. Curr Vasc Pharmacol 2007, 5(4):276-92.

2. Kelly, et al:. Am Heart J 1985, 110(3):535-41.

3. Price JF, et al:. Eur Heart J 1999, 20(5):344-53.

4. Weisz G, et al:. Am Heart J 2005, 150(2):358-64.

5. Heusch G, et al:. Cardiovasc Res 2012, 94(2):237-45, Epub 2011 Oct 16.

doi:10.1186/1532-429X-15-S1-0107

Cite this article as: Durighel et al:: Paradoxical effect of smoking

following acute myocardial infarction. Journal of Cardiovascular Magnetic Resonance 2013 15(Suppl 1):0107.

\section{Submit your next manuscript to BioMed Central} and take full advantage of:

- Convenient online submission

- Thorough peer review

- No space constraints or color figure charges

- Immediate publication on acceptance

- Inclusion in PubMed, CAS, Scopus and Google Scholar

- Research which is freely available for redistribution

Submit your manuscript at www.biomedcentral.com/submit
C Biomed Central 